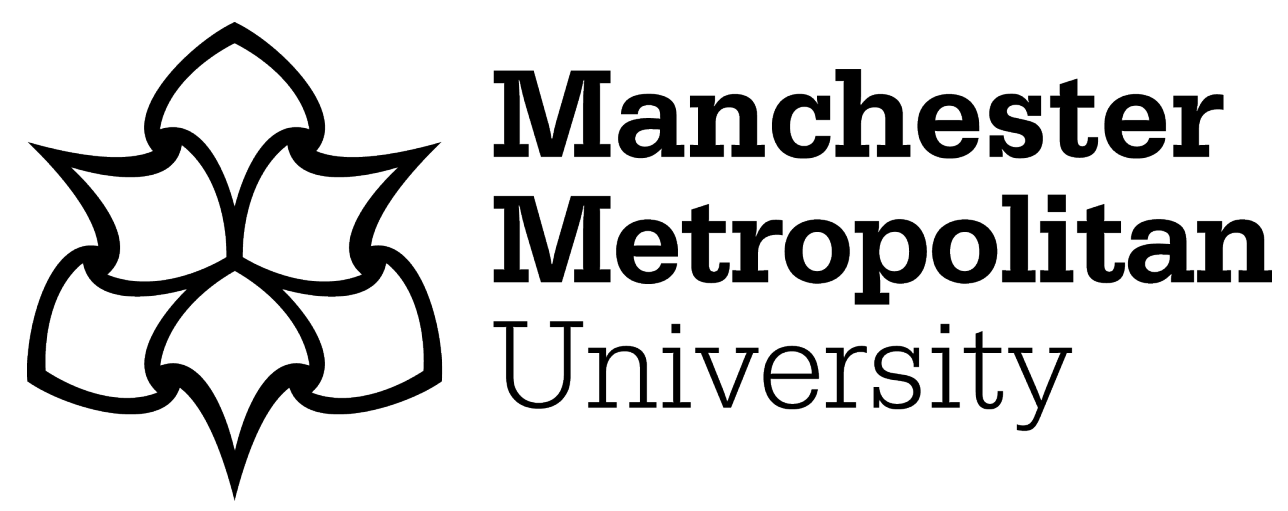

Herrero, Carmen ORCID logoORCID: https://orcid.org/0000-0002-13924224 (2020) The Beyond Babel Multilingual Film Festival. Journal of Film and Video, 72 (1-2). ISSN 0742-4671

Downloaded from: https://e-space.mmu.ac.uk/623750/

Version: Accepted Version

Publisher: University Film and Video Association

DOI: https://doi.org/10.5406/jilmvideo.72.1-2.0033

Please cite the published version 
Pre-print manuscript: journal article chapter for the Journal of Film and Video. Issue: 72:1-2 (Spring/Summer 2020)

\section{The Beyond Babel Multilingual Film Festival}

\section{Carmen Herrero}

The evident proliferation of film festivals, particularly since the 1990s, and their increasing impact on film production and circulation has drawn the attention of a growing number of film scholars. As Thomas Elsaesser notes in European Cinema: Face to Face with Hollywood, the shift toward studying the film festival as an institution and a cultural event is the "missing link" in film studies (83). Film festival research has focused on different areas. For instance, the methodology for the study of film festivals gravitates more towards interdisciplinary approaches (anthropology, cultural studies, film history, etc.) (De Valck et al.). From the perspective of film historiography, scholars have studied the evolution of international film festivals (De Valck; De Valck et al.). The "spatial logics" of the festival circuit have been discussed in relation to the local specificity (city) and the national and global discourses (Stringer 138; Iordanova, The Film Festival Reader; Iordanova "The film festival as an industry node"; Iordanova and Rhyne; Iordanova et al.; Iordanova, The Festival Reader 2009, 2013, 2015).

Other film festival scholarship works have explored ideological matters such as the role of film festivals in promoting political agendas and engaging in identity building (lordonova and Cheung). Indeed, festivals are spaces of mediation that can stimulate discussions on a wide range of issues, including aesthetic, economic, political and social aspects. They can function "as a place for the establishment and maintenance of cross-cultural-looking relations" (Stringer 134). While the work around film festival studies has focused mainly on the analysis of the significance, value and curational work of international festivals (such as Cannes, San Sebastian, 
Sundance), there are fewer studies focused on small-scale festivals, particularly those organized by universities. ${ }^{i}$ We seek to contribute to filling the gap in the research and literature in this interdisciplinary field by considering more specifically how the organization of film festivals can bridge communities and university constituencies.

The focus of this paper is the Beyond Babel Film Festival, a small multilingual film festival launched in 2015 as part of the Manchester Metropolitan University Humanities in Public Festival (HiP). It presents the festival's principal aims and the challenges of curating a multilingual-film programme. The research questions I deal with in this article are twofold: How a university film festival based on screening multilingual films could attract a wider and more diverse audience? How the educational strand of the project can enhance the critical appreciation of film, encourage and support language learning, and heighten the appreciation of other cultures?

First, this article introduces briefly the origin of the festival as part of the public programming at the Manchester Metropolitan University (UK). As this type of event revolves around public engagement and scholarly research, it examines the conceptual and practical frameworks about the role of university (film) festivals in the local and regional creative economy. The second section locates the research presented in this essay in an interdisciplinary space related to film, languages and festivals (language, applied linguistics, film festival, critical event and citizenship studies) and cultural and educational practices linked to the promotion of media and language literacies. The following section outlines the evaluative approaches used during the development of the Festival. The final part of this study examines the preliminary findings and summarizes some of the broader themes and traits and ideas that have emerged from the questionnaires, interviews and observational data. We will bring a conclusion weighting the value of small- scale 
film festival aimed at connecting higher education and communities and fostering curiosity about films, cultures and languages.

\section{The origin and aims of Beyond Babel (a multilingual film festival)}

Manchester is located in the northwest of England and it is the $6^{\text {th }}$ largest city in the United Kingdom with an estimated population of over 541,300 in 2016 (Office for National Statistics). It is the main city of Greater Manchester metropolitan county, an area with a population of more than 2.55 million. After London and Edinburgh, Manchester is the third largest economy in the United Kingdom. In 2014, the government signed the historical devolution deal known as 'Northern Powerhouse', starting an on-going process to give the region power and further freedom over its economic development to boost the region's economy and create a 'self-reliant' population by gaining greater influence over skills training provision. Policy-making for the arts and culture fulfils an important function in the implementation and impact of the devolution agenda in Greater Manchester. As noted by Abigail Gilmore, "as local authorities become more enablers than funders, artists and organisations will be asked to play increasingly independent roles as mediators, entrepreneurs, strategists and advocates of the ways in which they can contribute to local place-making”.

The central role of cities in the approach to cultural planning and the concept of creative industries has received increasing attention in policy discourses. An important aspect of these discussions relates to the relationship between economy and culture, on the one hand, and place and creativity, on the other. Aiming to be a thriving and sustainable city, Manchester is an excellent paradigm of the "creative city" approach (Landry 173). Known as a leader in creative 
and media businesses, ${ }^{\text {ii }}$ Manchester hosts large organisations such as the BBC and ITV and has a world class reputation for developing creative content in broadcast media, creativity, design and new digital platforms. A key ingredient in the policy planning is for the city to develop clusters that are internationally distinctive, and the presence of universities is instrumental for the creation, support and stability of these networks (Chapain and Comunian). ${ }^{\text {iii }}$ One of these clusters involves creative and media businesses that build on the research and knowledge exchange provided by the Manchester Metropolitan University, University of Manchester, and the University of Salford. Furthermore, as in the case of the Manchester Metropolitan University, the strategic plan builds around five pillars: Place (Manchester), Ambition, Partnership, Community, and Sustainability (my own emphasis).

Festivals "can feed into the cultural sectors in ways difficult to measure" (O'Connor 150). Placebased community and arts festivals play an important role in placemaking. Particularly in an era of austerity, these events are "significant mechanisms for social and urban renewal" (Millington and Platt). In her PhD on Universities and Festivals, Cultural Production in Context, Laura Ager examines a series of festivals produced by universities in the UK as meta-texts that could illuminate changes in the political culture within higher education. She notes that these activities are "a mechanism for public engagement and for the development of impact case studies" for the Research Assessment (Ager 251). ${ }^{\text {iv }}$ However, she also points out how a festival is also "a site of intervention into the public space" (Ager 269); and the fact that some participants - organizers "have self-reflexively identified a duality between their activist identities and the roles they performed at institutions" (Ager 270). Most importantly, she suggests that the production of a festival by a university can be understood as a response to the changing conditions in higher 
education, socio- political and economic factors, as well as changes in national and international policies. In her own words:

A festival can be seen as a method itself, to make an intervention in the realm of social exchanges. Because festivals are episodic and cyclical events, they mark time, creating temporally and spatially bounded opportunities for interaction, experimentation and exhibition, in between there is a reflexive process, it can be looked forward to and looked back on. A festival is an unusually intense period of creative activity that requires partnerships and teamwork to bring together a range of selected discourses and cultural forms. (Ager 273)

Virgine Mamadough and Nesrin El Ayadi argue that linguistic diversity and multilingualism are now common feature of European cities. Part of the "attractiveness" of Manchester for business operating globally is the fact that the city has a "diverse population with its vast array of languages and cultures", according to a Manchester City Council report that summarizes the Manchester Strategy 2016-2025 (an overarching framework and priorities for action by the City Council and partners from all sectors). However, cultural events that celebrate multilingual life are rare and multilingual city dwellers are often overlooked.

The Beyond Babel Festival started as part of the annual Humanities in Public (HiP) festival, a series of events organized by the Institute of Humanities and Social Science Research (IHSSR) at Manchester Metropolitan University. The development of HiP was underpinned by the need to contribute to the debate on the value of Humanities and the importance of quality public engagement with research. Another objective was to develop interdisciplinary cooperation with different communities. HiP included different types of activities (exhibitions, films screenings, 
inaugural lectures by new professors, one-day symposia, film screenings, guided walks, etc.) organized around strands that are curated or convened by academics working at the university. The $1^{\text {st }}$ edition of the Beyond Babel Festival took place on 14 March 2015 during the second HiP festival programme within the strand Multilingual Life, which aimed to celebrate language diversity and the process of communication across social groups and generations in intercultural and interpersonal encounters. The talks and events' main goal was to "embrace the beauty of multilingualism by highlighting various aspects of the ways in which our lives are enriched by linguistic variation in all its guises" (HiP). The programme included four events: a talk on "Urban youth identity and language", a panel discussion on English as Lingua Franca, three Bilingual cafes, and the Beyond Babel Film Festival. Following the model of "festival within a festival"", it involved presentations by a guess speaker and academics from the Manchester Metropolitan University, and a closing Q\&A session for the three screenings: Until The End of the World (Wim Wenders 1991), Pot Luck (Cédric Klapisch 2002), and Patagonia (Marc Evans 2010). ${ }^{\mathrm{vi}}$

Taking into consideration participants, speakers and collaborators' informal feedback from the first event, we felt encouraged to organize a second edition of the Festival as part of a new strand addressing key issues of social welfare and cohesion across the world. The iteration was more modest in terms of the number of films, kept the same format (one-day festival) but was a free event held at No70 Oxford St, formerly known as Cornerhouse, an emblematic building associated with independent art cinema screenings and arts exhibition. The second edition of the festival took place on Saturday 7 May 2016. The first film, Amreeka (2009), was introduced by Manchester Metropolitan University PhD candidate Hanan Ben Nafa, whose project focused on bilingualism and social identity ("Code-Switching and Social identity construction among 
Arabic-English bilinguals"). Hanan, who participated as student ambassador in the first festival, suggested this title during an informal interview organized after the event. Her collaboration illustrates the participatory approach that we have tried to implement in this project. Amreeka, a USA/ Canada/ Kuwait production directed by Cherien Dabis, tells the story of single mother, Muna, who moves with her son Fadi, from the occupied West Bank to the USA. The film shows the challenges of their new life both at micro-level (i.e. finding a job, Fadi's integration in high school, the prejudices they encounter, and the dilemmas on the use of English and their mother tongue) and at macro level (i.e. the fear and suspicion that surrounded Arabs living in the United Stated in the aftermath of 9/11). The second film was introduced by Dr Isabelle Vanderschelden, Senior Lecturer from the Manchester Metropolitan University and a member of the research group Film, Languages and Media Research Group (FLAME). Samba (2014), directed by Olivier Nakache and Eric Toledano, subtly mixes drama and humour to explore different human conflicts related to migration in France. The feedback collected by the HiP team was very positive and lauded the film choices. Overall, in the words of one of the participants, they "enjoyed the idea of looking at multiculturalism through the cinematic lens."

To comprehend how to respond to this need and cater for different communities, a number of questions were pivotal in the first phase of the research project that we are presenting in this article: What is the best format for cultural practices that engage and attract a wide range of language speakers? What is the relevance of the space and location? What are the best genres and themes for a "multilingual festival"? How can this type of festival bring together scholarly research and public engagement? What type of educational resources can be created to foster greater awareness of the power of film to create a dialogue about cultures, multilingual life and 
film cultures? How can the festival support the learning of languages both in informal and formal settings (particularly at secondary and tertiary levels)?

Since the first edition of the festival my objective was to organize a one-day film festival that could contribute to opening up discussions around film, cultures and languages in order to value the richness of multilingual life within the local and diasporic communities in Greater Manchester. The original idea came from my personal research interest in the interdisciplinary field of language and film studies, as director of the research group Film, Languages and Media in Education (FLAME) and co-founder and co-director of the Film in Language Teaching Association (FILTA), a community of practice with over 4,300 members from 120 countries (Herrero). The first overarching research question was the following: How can the partnership of film, media education and language learning promote and enhance the study of languages and contribute to the UK media strategic priorities agenda? Over the last decade, there have been recommendations at national and European level to encourage greater diversity in the range of languages on offer, including 'regional/minority' and 'migrant' languages for a wide range of purposes. Supporting languages can help to preserve a rich collection of cultural assets, often with links to the history of the town, city or regions in which communities are located. However, different publications have reported on the pressing need to support both formal and informal opportunities to study languages in all educational sectors and "to identify ways in which these could be developed to meet the needs and realise the potential of the UK's increasingly multilingual population" (McPake et al. 14) vii. Despite the evident merit of learning a second language, the diminishing popularity of languages in secondary schools and sixth-form colleges since the late 1990s and early 2000s has accentuated the drop-in uptake of language degrees in the UK (British Council). A recent multi-authored feature in the Times Higher Education, with 
contributions from modern linguists from/in Australia, Denmark, the UK and the US, looked at the new shape of the discipline. After weighing the challenges and priorities that can lead to recruiting more students for modern language courses at university level, these scholars offer a wide range of proposals ranging from growing a research-led discipline (Forsdick) to "communicating to the wider public the value of languages and cultural studies" (VerstraeteHansen). Another contributor to the Times Higher Education feature, Gramling, points out the need to revise curricula content and offer relevant courses "grounded in the lived complexity of societal multilingualism” (Gramling, "Do We Need Modern Language Graduates”).

Secondly, this study was being conducted at a point in time at which the British Film Institute started the BFI Film Audience Network (BFI FAN). ${ }^{\text {viii }}$ As outlined in Film Forever, the BFI's plan for 2012-2017, the FAN ambition was to encourage people to build a lifelong relationship with film, to help build audiences for a broader range of films across all platforms and ensure that film culture can be accessed and enjoyed by everyone across the UK. ${ }^{\text {ix }}$ The aim is to engage the widest possible audiences by creating a greater diversity of content and programming, facilitating a greater access and understanding of culturally diverse films, and increasing screenings of foreign language films.

The practice and representation of mutilingualism require a brief examination of the concepts of multilingualism and plurilingualism in relation to language studies on the one hand, and the definition of polyglot films, on the other. Scholarship on multilingualism has noted the overlaps and discrepancies in the description of multilingualism and plurilingualism (Rosello; Davies González). A useful distinction is offered by the Common European Framework of Reference for Languages (CEFR): 
Plurilingualism differs from multilingualism, which is the knowledge of a number of languages, or the co-existence of different languages in a given society $[\ldots]$ languages and cultures are not kept in strictly separated mental compartments, but rather build up a communicative competence to which all knowledge and experience of language contributes and in which languages interrelate and interact. (Council of Europe, Common European Framework 4)

This differentiation is also influencing current language learning approaches, with a stronger trend moving "from learning monolingually to learning plurilingually", which takes into consideration the mother tongue of the learners and the existence of previously known language(s) (González Davies 10). The multilingual perspective stresses the value of plurilinguistic affordances, including intercultural and mediation skills (Council of Europe, Common European Framework; Council of Europe, CEFR Companion Volumen; Byram). In The Invention of Monolingualism, David Gramling explores how multilingualism has been disciplined in monolingual ways. He calls for an interdisciplinary approach that requires alternate routes: "through insight and data gained from such ostensibly non-literary events as legislative committee sessions, personal testimonies, public happenings, language memories, promotional campaigns, translation protocols, online threads, fuzzy algorithms, student testimonies, paratextual features, and experiences of formal and informal learning, all of which exert pressure on how we come to define multilingualism and monolingualism today" (The Invention of Monolingualism 42). ${ }^{\mathrm{x}}$

The Beyond Babel Film Festival's mission was also to showcase films that broaden the representation of multilingual communities on screen and give more visibility to alternative 
examples of transnational and word cinema. The relevance of the plurilingual component in filmmaking has been attracting more attention since the publication of Ella Shohat and Robert Stam's outstanding article "Cinema After Babel: Language, Difference, Power". In fact, a recent volume edited by Tijana Mamula and Lisa Patti reveals the importance of multilingualism in filmmaking practices and "advocates the opening of film studies to a broader appreciation of the ways in which linguistic difference has shaped, and continues to shape, the medium's history" (Mamula and Patti 2). A line of enquiry in this field is the role of language diversity in films. For example, Tessa Dwyer argues that polyglot films are defined by the naturalistic presence of two or more languages at the level of dialogue and narrative. Likewise, other scholars maintain that multilingualism is not a simple decorative component as it plays a central role in the narrative of contemporary films (Gramling, "On the Other Side"; O'Sullivan). Chris Wahl, for example, has analysed the emergence of a new genre, 'polyglot films', that encompasses different subgenres (existential, globalization, colonization, fraternization and migration film). The last one has been particularly relevant in European cinema since the 1990s as a way of representing the consequence of the global realities of migration and diaspora. For Wahl, a polyglot film "respects the cultural 'aura' and the individual voices of the actors, delivers on a verbal level a naturalistic depiction of the characters, but often has an articulately disillusioning effect because of the use of subtitles" (Wahl 338). In Polyglot Cinema: Migration and Transcultural Narration in France, Italy, Portugal and Spain, Verena Berger and Miya Komori defend that "the central tenet of polyglot cinema is the representation of language diversity as its protagonists experience it" (Berger and Komori 9). While Gemma King, in Decentring France: Multilingualism and Power in Contemporary French Cinema has focused on different case 
studies demonstrating the function of multilingualism as a "crucial narrative element, a tool and a strategy for wresting, maintaining and redistributing power among the characters" (King 27).

\section{Methodology}

Critics, programmers and festival directors as well as academics contribute to offer the perspectives of "insiders" and "outsiders" (terms used by lordanova in her introduction to The Film Festival Yearbook 1). The addition of a perspective from the inside has also been used by film scholar Cindy Hing-Yuk Wong in her book Film Festivals: Culture, People, and Power on the Global Screen. My take on the subject shares some similarities with these approaches as it is based on my own experience as organizer and curator of the Beyond Babel Festival, and as an academic and researcher interested in putting theory into practice in the context of a local academic film festival, designed as cultural production and community engagement. The present study examines the audience's expectations and the aspects that were more appealing about the festival, particularly the multilingual focus of the event, the feedback on the film and suggestions of thematic strands, films and languages for future editions. To examine the themes and trends emerging from the festival participants comments, coding was undertaken using a qualitative data analysis. The development of qualitative research questions tends to be vague in the initial stages of research and in the absence of a consolidated body of prior research on film festival, languages and media literacy, this study adopted a Grounded theory approach to analyse the data, with the aim of generating insights that will ultimately form the basis for theory-making. In the field of qualitative research, Grounded theory has been used across different disciplines:

Grounded theory involves taking comparisons from data and reaching up to construct abstractions and then down to tie these abstractions to data. It means learning about the 
specific and the general—and seeing what is new in them — then exploring their links to larger issues or creating larger unrecognized issues in entirety. An imaginative interpretation sparks new views and leads other scholars to new vistas. Grounded theory methods can provide a route to see beyond the obvious and a path to reach imaginative interpretations. (Charmaz, Constructing Grounded Theory 181)

The Grounded Theory Method (GTM) adopts "a systematic, inductive, and comparative approach for conducting inquiry for the purpose of constructing theory" (Bryant and Charmaz 1). However, the original idea of pure induction and the delay of literature review -as postulated in 'classic' Grounded theory, has been problematized. As an alternative to a lack of preliminary expertise in the field, constructive grounded theorists "advocate recognizing prior knowledge and theoretical preconceptions and subjecting them to rigorous scrutiny" (Charmaz, "Constructionism and Grounded Theory" 402). The method is designed to encourage researchers to use the pre-existing theories and persistent interaction with their data "in a sensitive, creative, and flexible way" (Thornberg 255). The GTM builds empirical checks into the analytic process and leads researchers to examine all possible theoretical explanations for their empirical findings. The iterative process of moving back and forth between empirical data and emerging analysis makes the collected data progressively more focused and the analysis successively more theoretical.

The study presented in this article was funded by the UK Arts and Humanities Research Council's Open World Research Initiative (OWRI) under the programme 'Cross-Language Dynamics: Reshaping Community', which aims to demonstrate the strategic importance of language-led research, and echoes the importance of multidisciplinary research in a multilingual 
world. ${ }^{\mathrm{xi}}$ It is based on research conducted between February 2017 and February 2018, during the 3rd and 4rd editions of the HiP festival. ${ }^{x i i}$ The 2016/17 HiP focused on a specific theme, "Greater Manchester and Northern Identity". The attention to the culture, languages and identities of the North West, locally and globally, was guided by the arrival of Greater Manchester Devolution. The third Beyond Babel Film Festival was set up with a very specific agenda: to recognize the complexity of education and language policy and to provoke discussion, debate, and reflection on language policy and migration. The two films were screened in the evening in the Geoffrey Manton Building, at the Manchester Met University. La cour de Babel / The School of Babel (Julie Bertuccelli, 2013) [France]. The documentary and the introduction and Q\&A session by Dr Isabelle Vanderschelden (Manchester Metropolitan University) raised important questions about multilingualism and language learning. It generated a debate around intercultural issues and education. The second film, The Colours of the Alphabet (2016) by Alistair Cole (UK/New Zealand) is a feature documentary shot over one year in rural Zambia. It follows thirty children starting primary education and their parents. It deals with the omnipresence of English, the official language of the country, in a country were less than $2 \%$ of Zambians use it in their daily interactions. The director was invited to introduce the film and participated in the Q\&A session following the screening. The third event included in this study was part of the $4^{\text {th }}$ edition of Beyond Babel, but this time it was offered as part of the New Mills Festival, on the 14th of September in Derbyshire, in collaboration with the Manchester Metropolitan University. The space was a very distinctive venue, the Spring Bank Arts. The screening followed the same pattern: an introduction, the screening of the film and a short Q\&A session. The Spanish comedy Requisitos para ser una persona normal / Requirements for being normal (2015), directed by Leticia Dolera, attracted a considerable number of film aficionados and language learners and 
speakers. The other free screenings took place on the 6, 7 and 8 February 2018. The French and Algerian production Né quelque part / Homeland (2012) is the feature debut of Mohamed Hamidi. It tells the story of Farid, a law student in France who is forced to travel for the first time to Algeria, his father's homeland. The film was screened at 70 Oxford St (Cornerhouse) and it was led by Isabelle Vanderschelden. El futuro perfecto / The Future Perfect (2014), an Argentine semi-fictional documentary in which German filmmaker Nele Wohlatz recounts the story of a young Chinese immigrant (Xiaobin) after her arrival in Buenos Aires and how this story reflects her experience of making a film in another language. The screening took place at the Instituto Cervantes in Manchester. Finally, English Vinglish (2012), an Indian comedy-drama film written and directed by Gauri Shinde, reflects on the process of mastering a language, and gaining the confidence that comes with it. All the films dealt with serious issues with a fine balance between humour and gravity. The film was screened in the main building of the Faculty of Humanities at Manchester Metropolitan University.

After getting ethical approval from Manchester Metropolitan University for this project, a postevent questionnaire was distributed after each screening. A total of 190 responses were returned. Semi-structured interviews were carried out with nine individuals who had previously attended the Festival in August and September 2017. The interviews, observation and other data collection methods (photography, videos, and reviews) were used to reinforced and validate the data obtained from the interviews. Six key themes were identified in the motivation for attending the festival: (1) film, (2) languages, (3) culture, (4) themes, (5) learning and (6) community. See appendix 1. 
Interest in film made up a large number of the responses regarding the main reason for attending the film festival. For instance, participants highlighted their preference for foreign films or films that they would not see "in mainstream theatre"'. Other participants valued the opportunity to watch multilingual films that "are sadly underrepresented". In addition, it is evident from the answer that participants were keen on certain genres (documentary/comedy) and the fact that it was an accessible free event.

The second key theme identified in this research is that the participants perceive the importance of languages, language learning and multilingualism. One of the participants writes: "I wanted my children to experience the multilingual culture and language". Language learning is often associated with enjoyment and the film experience: "Love film, love languages and different cultures". The film is also seen as a chance to improve the language they are learning. There are also language students interested in developing their language skills.

Within the theme of culture, participants' contributions singled out their interest in other cultures: "I wanted to see a film about places and culture that I don't know much about". Comments often emphasise cultural links (travelling, language learning, work experience) and family connections: "My heritage is Middle Eastern (father) and English, so I saw parallels to having a mixed background”. Socializing with friends and relatives presents the event as a culturally attractive activity.

A large number of responses also highlighted the film themes for attending the screening. Migration, multiculturalism and diversity are the most frequent words used. For example, one participant says: "Interested in immigration from Africa to Europe as well". And other mentions professional interest: "Found subject matter interesting. I work in a multicultural school with many EAL children”. Interest in political and social issues, particularly during the Brexit 
negotiations, was reflected in the feedback. For example, one participant reflected: "Language and theme of "foreigners" after Brexit propaganda against". And one comment referred to expanding knowledge on this topic: "I wanted to know more about refugees as I only see it on the news, therefore I wanted to know more". Moreover, language learning is another component of the thematic strand: "I found it useful to know more about how films can help learn and teach languages".

Learning appears frequently to be linked to the format of the event. In the responses, it is evident that participants were greatly appreciative of the opportunity to learn through the films and Q\&A sessions. Numerous responses describe their interest in the introduction and/or the director presenting the film. The event is considered as an opportunity of learning about new topics and intellectual curiosity. Furthermore, for teachers and secondary school pupils the festival provided an opportunity to enhance the school curricula: "I think it is great to improve my French. I attended with my school". Other participants were seeking to develop their film education and creative practice as filmmakers.

The last theme is community. The positive perception of the venue was visible when the event took place at 70 Oxford Street (the Cornerhouse cinema). In the case of the screening that was offered as part of the New Mills Festival, participants tended to comment on the proximity of the event ("near home" and "easily accessible") and the surrounding. Community engagement was also associated to this event.

The post-questionnaire gave the participants the opportunity to nominate future thematic strands, films and languages, as seen in Appendix 2. ${ }^{\text {xiii }}$ Many participants were very satisfied with the festival. However, it is notable that many requested more films, more languages and social activities and resources related to language learning and multilingualism (i.e. language taster 
sessions, events to promote the benefits of a second language, etc.). The festival has produced study guides based on the films screened aimed at supporting language learning using audiovisual materials and developing critical appreciation of films. These free resources, published using creative common licences, are available to download from FILTA and FLAME (https://flameresearchcentre.wordpress.com/home/beyond-babel/).

\section{Conclusion}

While this research found that participant expectations and motivations for attending vary considerably, the themes that emerge across the comments show how film festivals organized by higher education institutions provide an ideal platform to engage with a wide range of individuals interested in films and languages. The staff-led introduction and discussions are recognized as an opportunity to explore and reflect on the importance of multilingualism in filmmaking practices and to account for the myriad complex processes related to linguistic diversity in past and present times.

Since this project is bound to notions of multilingual life, place and identities, it plays a crucial role in building and maintaining relationships with different language communities. The project aims to promote a positive perception of language learning and the value of multilingual communities for the city and the Greater Manchester region whilst challenging negative perceptions related to multilingual life and migration. Furthermore, it endevours to advance understanding of the cultural value of university-led festivals. Further research could explore how events for migrants and minority ethnic community advance and enrich the main objectives of the festival. Also meriting attention is further exploration of how attending the festival may influence secondary student perception of the importance of language learning and arts. 
The production of the resources (film study guides and interviews) will serve as a permanent, publicly available resource which we will use to communicate our research findings to date and to engage in meaningful dialogue with the public regarding perceptions of multilingual life and film.

\section{Funding}

This work was supported by the UK Arts and Humanities Research Council's Open World Research Initiative (OWRI) under the programme 'Cross-Language Dynamics: Reshaping Community; and the Manchester Metropolitan University

\section{NOTES}

${ }^{\mathrm{i}}$ This is not unique to the UK. Charles Musser and Patricia Zimmermann, in their paper abstract "Generating Cultural Resources: Film Festivals and Public Programming at Colleges and Universities" for the 2018 SCMS Conference held in March 2018 in Toronto, remark that little attention has been paid to "the function and specific value of festival exhibition practices in more modest settings such as festivals housed at, or associated with, academic institutions and situated in local communities."

${ }^{\text {ii }}$ Greater Manchester is considered the second largest hub for creative and digital content across Europe after London.

iii An excellent example has been the successful bid to join UNESCO's worldwide Creative Cities network as a City of Literature in recognition of its outstanding contributions to literary culture and its strong literacy history. Reportining it, The Guardian makes clear reference to the contribution of the Manchester Writing School at Manchester Metropolitan University and the Centre for New Writing at the University of Manchester, as well as the Manchester International Festival.

iv The REF is the UK's system for assessing the quality of research in UK higher education institutions (www.ref.ac.uk/about/).

${ }^{v}$ This model was already present in the first edition of the HiP festival with the Gothic Manchester Festival, organized by the Centre for Gothic Studies in the Department of English at Manchester Metropolitan University. ${ }^{v i}$ Speakers on the day included Isabelle Vanderschelden and Benedicte Brahic (from Manchester Met), and guest speaker Barnaby Dicker (Royal College of Art, London). There was a ticket fee (£5), which contributed to cover part of the expenses (film licenses, hiring the space and lunch). Sixty people attended this event.

vii The principal policy arguments put forward to support a wide range of languages are the following: "a multilingual workforce is needed for the UK to maintain and enhance its share in international business; the study of other languages brings intellectual and cultural benefits and contributes to global citizenship; skills in other languages are now, and will increasingly be, essential to participation in the information society" (McPake et al.). viii The BFI FAN funding is distributed between the UK Film Hubs and is used to support a range of audience development activities at a local, regional and cross-regional level. The Hub Lead Organisations across the UK have collectively receive BFI lottery funding of up to $£ 7.5 \mathrm{~m}$ over four years (2013-17) to bring new film experiences to UK.

ix Film Forever: Supporting UK Film 2012-2017 outlines the BFI's three key strategic priorities as: Education and audiences; British film and filmmaking; and Film heritage. 


\footnotetext{
${ }^{x}$ Gramling continues "These arenas of production are alive with a kind of emergent multilingual literacy [...] that requires new conceptions of authorship, civic personhood, pedagogy and semio-diverse research methods" (The Invention of Monolingualism 42).

${ }^{x i}$ Cross Language Dynamics Project http://projects.alc.manchester.ac.uk/cross-language-dynamics/

xii Since 2018 the public engagement programme of the Faculty of Arts and Humanities at Manchester Met has been re-named RAH! (Research in Arts And Humanities at Manchester Met www2.mmu.ac.uk/artshumanities/rah/).

xiii From the quantitative information that has been obtained from the questionnaires, it is significative the number of languages spoken by participants (10-15 in each screening). While the majority of those attending have English as mother tongue, $90 \%$ declare that speaks at least one other language. The same percentage of participants $(90 \%)$ value highly the use of film to promote multilingualism and intercultural awareness and consider the theme of multilingualism as one of the most important reasons to attend the festival.
}

\section{REFERENCES}

Ager, Laura C. Universities and Festivals: Cultural Production in Context. University of

Salford, PhD dissertation, 2016, usir.salford.ac.uk/id/eprint/41034/1/Final\%20copy\%20of\%20thesis_Laura\%20Ager_Salford.pdf

Berger, Verena, and Miya Komori, eds. Polyglot Cinema: Migration and Transcultural

Narration in France, Italy, Portugal and Spain. Verlag Münster, 2010.

Beyond Babel Film Festival. The Byond Babel Film Festival. May 2019, www.facebook.com/BeyondBabelFilmFestival/

British Academy. 2016. Born Global. British Academy, 2016.

British Film Institute. BFI Film Audience Network. British Film Institute, 2016.

British Film Institute. BFI Film Forever. British Film Institute, 2016.

Bryant, Antony, and Charmaz, Kathy. The SAGE Handbook of Grounded Theory. SAGE, 2007.

Byram, Michael. From Foreign Language Education to Education for Intercultural Citizenship:

Essays and Reflections. Multilingual Matters, 2008. 
Chapain, Caroline, and Roberta Comunian. "Enabling and Inhibiting the Creative Economy: The Role of the Local and Regional Dimensions in England.” Regional Studies, vol. 44, no. 6, 2010, pp. 717-734.

Charmaz, Kathy. Constructing Grounded Theory: A Practical Guide through Qualitative Analysis. Sage, 2006.

Charmaz, Kathy. Constructionism and Grounded Gheory. Handbook of Constructionist Research, edited by James A. Holstein and Jaber F. Gubrium, The Guilford Press, 2007, pp. $397-412$.

Council of Europe. Common European Framework of Reference for Languages: Learning, Teaching, Assessment. Cambridge University Press, 2001.

Council of Europe. Common European Framework of Reference for Languages: Learning, Teaching, Assessment. Companion Volumen with New Descriptors. Council of Europe, 2018. De Valck, Marijke. Film Festivals: From European Geopolitics to Global Cinephilia. Amsterdam University Press, 2010.

De Valck, Marijke, et al. eds. Film Festivals: History, Theory, Method, Practice. Routledge. 2016.

Dwyer, Tessa. "Universally speaking: Lost in Translation and Polyglot Cinema." Linguistica Antverpiensia, New Series-Themes in Translation Studies, vol. 4, 2005, pp. 295-310.

Elsaesser, Thomas. European Cinema: Face to Face with Hollywood. Amsterdam University Press, 2010.

FLAME. Film, Languages and Media in Education, www2.mmu.ac.uk/languages/flame/. Accessed 23 May 2019.

FILTA. Film in Language Teaching Association, www.filta.org.uk. Accessed 23 May 2019. 
Forsdick, Charles. "Do We Need Modern Language Graduates in a Globalised World?.” The Times Higher Education, 23 Feb. 2017. www.timeshighereducation.com/features/do-we-needmodern-language-graduates-in-globalised-world. Accessed 10 May 2019. González Davies, María. “Towards a Plurilingual Development Paradigm: From Spontaneous to Informed Use of Translation in Additional Language Learning". The Interpreter and Translator Trainer vol. 8, no. 1, 2014, pp. 8-31.

Gramling, David. 'On the Other Side of Monolingualism: Fatih Akın's Linguistic Turn (s) 1." The German Quarterly, vol. 83, no. 3, 2010, pp. 353-372.

Gramling, David. “ Do We Need Modern Language Graduates in a Globalised World?.” The Times Higher Education. 23 Feb. 2017. www.timeshighereducation.com/features/do-we-needmodern-language-graduates-in-globalised-world. Accessed 10 May 2019. Gramling, David. The Invention of Monolingualism. Bloomsbury Academic, 2016. Gilmore, Abigail. "Why Arts and Cultural Policy Matter in the Devolution Debate". April 2016, http://blog.policy.manchester.ac.uk/urban/2016/04/why-arts-and-cultural-policy-matter-in-thedevolution-debate/. Accessed 10 Dec. 2018.

Herrero, Carmen. “The Film in Language Teaching Association (FILTA): a multilingual community of practice.” ELT Journal, vol. 70, no. 2, 2016, pp. 190-199.

doi.org/10.1093/elt/ccv080

HiP. “Multilingual Life.” Sep. 2014. www2.mmu.ac.uk/hip/events-archive/201415-hip-festival/. Accessed 10 Dec. 2018.

lordanova, Dina. Digital Disruption: Cinema Moves On-Line. University of St. Andrews, 2012. lordanova, Dina. The Film Festival Reader. St. Andrews, University of St. Andrews, 2013. 
Iordanova, Dina. "The Film Festival as an Industry Mode.” Media Industries Journal vol. 1, no. 3, 2015, pp. 7-11

lordanova, Dina, and Ragan Rhyne, eds. Film Festival Yearbook 1: The Festival Circuit. St. Andrew Film Studies, 2009.

Iordanova, Dina, and Ruby Cheung. Film Festival Yearbook 2: Film Festivals and Imagined Communities. St Andrews Film Studies, 2010.

King, Gemma. Decentring France: Multilingualism and Power in Contemporary French Cinema. Oxford University Press, 2017.

Landry, Charles. The Creative City: A Toolkit for Urban Innovators. Earthscan, 2000.

Mamadouh, Virginie, and Nesrin El Ayadi. "Van Mokum naar Damsko, and Back Again? Deep Language Diversity and the New Urbanity." Urban Europe: Fifty Tales of the City, edited by. Virginie Mamadouh and Anne van Wageningen, Amsterdam University Press, 2016, pp. 59-66. Mamula, Tijana, and Lisa Patti, eds. The Multilingual Screen: New Reflections on Cinema and Linguistic Difference. Bloomsbury Publishing, 2016.

McPake, J., I. Sachdev, T. Carroll, T. Birks and A. Mukadam. Community Languages in Higher Education: Towards Realising the Potential. Routes into Languages, 2008.

www.routesintolanguages.ac.uk/community/index.html. Accessed 5 March 2015.

Millington, Steve, and Louisa Platt. Festival Evaluation: Worshop Preliminary Findings. Manchester Metropolitan University and Institute of Place Management, 2017. O’Connor, Justin. Cultural Production in Manchester: Mapping and Strategy. Manchester Institute for Popular Culture, Manchester Metropolitan University, 1999. 
O’Sullivan, Carol. "Multilingualism at the Multiplex: a New Audience for Screen Translation?." Linguistica Antverpiensia, New Series-Themes in Translation Studies, vol. 6, 2007, pp. 81-95.

Rosello, Mireille. "Plurilingual Europeans in a Multilingual Europe: Incomplete and Imperfect

Communication Tactics Introduction to Part II.” European Studies, vol. 29, 2012, pp. 215-233.

Shochat, Ella, and Robert Stam. "The Cinema After Babel: Language, Difference,

Power." Screen, vol. 26, no. 3-4, 1985, pp. 35-58.

Stringer, Julian. "Global Cities and the International Film Festival economy." Cinema and the City: Film and Urban Societies in a Global Context, edited by Mark Shiel and Tony

Fitzmaurice, Blackwell Publishers, 2001, pp. 134-144.

Thornberg, Robert. "Informed Grounded Gheory." Scandinavian Journal of Educational

Research, vol. 56, no. 3, pp. 2012, pp. 243-259.

Verstraete-Hansen, Lisbeth. "Do We Need Modern Language Graduates in a Globalised World?", The Times Higher Education. 23 Feb. 2017.

www.timeshighereducation.com/features/do-we-need-modern-language-graduates-in-globalised-

world. Accessed 10 May 2019.

Wahl, Chris. 'Du Deutscher, Toi Français, You English: Beautiful!'-The Polyglot Film as a Genre." Shifting Landscapes: Films and Media in European Contexts, edited by Miyse

Chistensen and Nezih Erdogan, Cambridge Scholars Publishing, 2008, pp. 334-350.

Wong, Cindy Hing-Yuk. Film Festivals: Culture, People, and Power on the Global Screen. Rutgers University Press, 2011. 
Appendix 1: Initial coding nodes aggregated into themes

\begin{tabular}{|c|c|c|}
\hline Node name & $\begin{array}{l}\text { Total } \\
\text { nodes }\end{array}$ & Main themes \\
\hline \multirow[t]{5}{*}{ Films } & \multirow[t]{5}{*}{84} & Film \\
\hline & & Foreign film \\
\hline & & Free film (event) \\
\hline & & Non-mainstream film \\
\hline & & Genre \\
\hline \multirow[t]{4}{*}{ Languages } & \multirow{4}{*}{44} & Languages \\
\hline & & Foreign language \\
\hline & & Multilingualism \\
\hline & & Language learning \\
\hline \multirow[t]{3}{*}{ Culture } & \multirow[t]{3}{*}{38} & Heritage \\
\hline & & Socializing \\
\hline & & International cultures \\
\hline \multirow[t]{7}{*}{ Themes } & \multirow[t]{7}{*}{36} & Migration \\
\hline & & Education and schools \\
\hline & & Multiculturalism and diversity \\
\hline & & $\begin{array}{l}\text { Women experiences (sexism, colonialism, } \\
\text { prejudices) }\end{array}$ \\
\hline & & Language learning \\
\hline & & Quirky topic \\
\hline & & Socio-political issues \\
\hline \multirow[t]{7}{*}{ Learning } & \multirow[t]{7}{*}{30} & Learn about people/new topics \\
\hline & & School curricula \\
\hline & & $\begin{array}{l}\text { Introduction to the film /Director presenting the } \\
\text { film }\end{array}$ \\
\hline & & Q\&A session \\
\hline & & Media/film education/creative practice \\
\hline & & Intellectual curiosity \\
\hline & & School curricula \\
\hline \multirow[t]{3}{*}{ Community } & \multirow[t]{3}{*}{18} & Community focused \\
\hline & & Community engagement \\
\hline & & Local event \\
\hline
\end{tabular}




\begin{tabular}{|l|l|l|}
\hline & Location/cinema/venue \\
& Informal style \\
\hline
\end{tabular}

\section{Appendix 2: Thematic strands and films, languages and other additional activities suggested by participants}

\begin{tabular}{|c|c|c|}
\hline Thematic strands & Languages & Other activities \\
\hline $\begin{array}{l}\text { Religion (Timbuktu) and } \\
\text { philosophy }\end{array}$ & Spanish & Short films \\
\hline $\begin{array}{l}\text { Migration, refugees and } \\
\text { diaspora }\end{array}$ & Arabic & More films \\
\hline $\begin{array}{l}\text { Culture, Culture } \\
\text { exchange/cultural adaptation } \\
\text { and intercultural experiences }\end{array}$ & French & $\begin{array}{l}\text { Social/networking } \\
\text { pre/post event }\end{array}$ \\
\hline Gender /Women/Feminism & African languages & Different venue \\
\hline LGBT & Easter European Languages & $\begin{array}{l}\text { Resources on } \\
\text { multilingualism }\end{array}$ \\
\hline Family and childhood & Italian & $\begin{array}{l}\text { Language learning } \\
\text { activities linked to the } \\
\text { language of the film } \\
\text { shown/ Language taster } \\
\text { sessions }\end{array}$ \\
\hline Identity & German & $\begin{array}{l}\text { Events to promote the } \\
\text { benefits of a second } \\
\text { language }\end{array}$ \\
\hline $\begin{array}{l}\text { National and political issues } \\
\text { (i.e. Brexit) }\end{array}$ & Irish & $\begin{array}{l}\text { Focus on ethnic } \\
\text { minorities }\end{array}$ \\
\hline $\begin{array}{l}\text { History and History of } \\
\text { language }\end{array}$ & Tamil & $\begin{array}{l}\text { Event about migrants for } \\
\text { migrants/refugees }\end{array}$ \\
\hline $\begin{array}{l}\text { Learning English as a second } \\
\text { language in Britain }\end{array}$ & Turkish & Director interview \\
\hline $\begin{array}{l}\text { The difficulties of learning a } \\
\text { language in a foreign country }\end{array}$ & Kurdish & $\begin{array}{l}\text { A round table with the } \\
\text { producer }\end{array}$ \\
\hline Class & Russian & Weekend event \\
\hline "Americanation" & Mandarin/Chinese & $\begin{array}{l}\text { Event for schools and } \\
\text { colleges }\end{array}$ \\
\hline African films & Farsi & More time for the debate \\
\hline Levantine Arabic Films & Basque & More publicity \\
\hline
\end{tabular}




\begin{tabular}{|l|l|l|}
\hline $\begin{array}{l}\text { Documentary about } \\
\text { Manchester }\end{array}$ & Japanese & \\
\hline Muslim community in the UK & Portuguese & \\
\hline $\begin{array}{l}\text { Black, Asian and Minority } \\
\text { Ethnic community in the UK }\end{array}$ & & \\
\hline
\end{tabular}

